Original Research

\title{
Evaluating Hexaconazole Leaching in Laboratory and Field Experiments: Effects of Application Rate, Soil Type, and Simulated Rainfall
}

\author{
Zainol Maznah*, Muhamad Halimah¹, B. Sahid Ismail ${ }^{2}$, Abu Seman Idris ${ }^{3}$ \\ 'Analytical and Quality Development Unit, Product Development and Advisory Services Division (PDAS), \\ Malaysian Palm Oil Board (MPOB), Selangor, Malaysia \\ ${ }^{2}$ School of Environmental and Natural Resource Sciences, Faculty of Science and Technology, \\ Universiti Kebangsaan Malaysia (UKM), Selangor, Malaysia \\ ${ }^{3}$ Ganoderma and Diseases Research for Oil Palm Unit (GanoDROP), Biological Research Division, \\ Malaysian Palm Oil Board (MPOB), Selangor, Malaysia
}

Received: 31 July 2017

Accepted: 27 September 2017

\begin{abstract}
In the present study we investigated the leaching behaviour of hexaconazole fungicide in two soil packed columns, namely disturbed and undisturbed soil columns in field conditions. The effects of simulated rainfall $(100 \mathrm{~mL}, 200 \mathrm{~mL}$, and $400 \mathrm{~mL})$ and application rate at recommended dosage ( $4.5 \mathrm{~g}$ a.i/palm tree) and double recommended dosage ( $9.0 \mathrm{~g}$ a.i $/$ palm tree) were also studied. The residual of hexaconazole in the soil column was observed to be significantly different between the volumes of simulated rainfall application and decreased with increased soil depth. The highest concentrations were detected at the soil surface $(0-10 \mathrm{~cm})$, where $53-63 \%$ of the hexaconazole remained after applications. No significant difference was found between the disturbed and undisturbed soil packed column when treated with the recommended and double recommended dosages of hexaconazole. In order to understand the hexaconazole leaching pattern, a field study experiment with the same soil properties and application rate was conducted. The results showed that hexaconazole was distributed downward through the preferential flow and soil crack in the sandy loam soil profile. The groundwater ubiquity scores (GUS) Index for hexaconazole calculated in Malaysian soil was 4.61, indicating that hexaconazole has a high risk of contaminating groundwater resources.
\end{abstract}

Keywords: mobility, GUS Index, application rate, simulated rainfall, soil column

*e-mail: maznahz@mpob.gov.my 


\section{Introduction}

Fungicide hexaconazole [(RS)-2-(2,4-dichlorophenyl) -1-(1H-1,2,4-triazol-1-yl)hexan-2-ol] is one of the triazole group that is most commonly used in farming for controlling fungi, particularly ascomycetes and basidiomycetes. As systemic fungicides with protective and curative action, hexaconazole was reportedly effective in controlling the white root disease in immature rubber and chrysanthemum - a powdery mildew on roses [1-2]. Other than that, the fungicidal treatments of hexaconazole as a preventive treatment for controlling Ganoderma disease in oil palm plantation have shown positive results [3].

An increasing number of studies on the mobility, leaching, dissipation, degradation, and solarization of triazole fungicides have shown high concern for this fungicide due to its long persistence in soil. Bromilow et al. [4] reported that triadimenol, flutriafol, and epiconazole were very persistent with $\mathrm{DT}_{50}>400$ days, while propiconazole had $\mathrm{DT}_{50}$ around 200 days under field conditions. Later, the same authors have investigated the degradation of triazole fungicides under laboratory incubations. They found the half-life $\left(t_{1 / 2}\right)$ for triadimenol, flutriafol, and epiconazole to be more than two years at $10^{\circ} \mathrm{C}$ and $80 \%$ field capacity, while propiconazole was less persistent at $t_{1 / 2} \sim 200$ days [5]. Recently, Zhang et al. [6] calculated that the half-lives of difeneconazole and propiconzole were from 4.9 to 5.8 and 6.1 to 8.4 days in soil, respectively. In our previous study, we have reported the $\mathrm{DT}_{50}$ of hexaconazole in soil from cultivated oil palm to be 69.3 and 86.6 days at single and double recommended dosage plots, respectively [7]. However, other studies have demonstrated that the half-life $\left(\mathrm{DT}_{50}\right)$ of triazole fungicide in different soil properties was less persistent in soil [8-9].

The transport of pesticide in soils depends on many variables such as soil properties (organic carbon content, structure), meteorological parameters (e.g., rainfall and temperature), and physical-chemical data of chemicals (e.g., water solubility, vapor pressure) [10]. Singh [11] found that penconazole, hexaconazole, and propiconacole were only moderately mobile instead of triadimefon, which was quite mobile in the low organic content sandy loam soils. Laboratory soil column studies have indicated that $41 \%$ of triadimenol found in leachate and hexaconazole and tebuconazole exhibiting the higher retention on the upper layer of soil [12]. Meanwhile, Sharma et al. [13] have reported that hexaconazole was found to be less mobile in all soil studied (alluvial, red, laterite, and black), and when the volume of water was increased, hexaconazole mobility increased through the upper layer of soil but did not move to the lower depths and leachates.

Even though there is a lot of literature available on degradation, dissipation, leaching, and mobility behaviour of triazole fungicide in an environment, not much information is available on mobility and leaching behaviour of hexaconazole in cultivated soil - particularly under Malaysian tropical conditions. Therefore, the objective of this study was to determine the leaching behaviour of hexaconazole in two conditions - laboratory and field study - and to investigate the effects of simulated rainfall and a different rate of applications of hexaconazole. The leaching potentials for hexaconazole by using the GUS Index were also to be calculated. The available data from this study are expected to provide preliminary data on the leaching behaviour of hexaconazole under tropical conditions in order to prevent contamination of hexaconazole into groundwater resources.

\section{Experimental}

\section{Chemicals}

Analytical-grade solvents and reagents were used throughout this study. The method for preparation of analytical standard grade of hexaconazole with $99.5 \%$ purity and commercial grade of hexaconazole (Anvil $4.8 \%$ a.i.) were carried out in accordance with the method as described by Maznah et al. [7].

\section{Soil Sample Preparation}

Soil samples were taken from the top layer $(0-20 \mathrm{~cm})$ of the site experiment plot and well homogenized. Soil samples were air-dried at room temperature and all the stones and macro-fauna were removed before being sieved to pass through a $2 \mathrm{~mm}$ sieve. The soil was classified as sandy loam and had low total organic carbon $(0.86 \%)$ and the following properties: clay $(27.29 \%)$, sand $(62.62 \%)$, silt $(10.09 \%)$, and $\mathrm{pH} 5.28$.

\section{Soil Column Study}

The soil column study was carried out in laboratory conditions in accordance with the standard method suggested by OECD [14]. In this study, polyvinyl chloride (PVC) tubes with an inner diameter of 8.5 $\mathrm{cm}$ were cut into $10 \mathrm{~cm}$ and reassembled into one tube with a height of $50 \mathrm{~cm}$. Then the PVC tube was filled to a height of $40 \mathrm{~cm}$ with the air-dried soil. Filter paper was used as a cover on the top of the soil to disperse the incoming flow and thus reduce the losses of soil due to heavy flow. The lower end of the soil column consisted of an aluminium layer that has been pierced $(2.0 \mathrm{~mm})$ to allow the leachate to flow out.

\section{Effect of Simulated Rainfall}

Eighteen soil PVC tubes were packed with airdried soil and randomly arranged on the bench in the greenhouse. Prior to the application of the hexaconazole, the soil PVC tubes were introduced with $200 \mathrm{~mL}$ 
$0.01 \mathrm{M} \mathrm{CaCl}{ }_{2}$ solution until field capacity was reached and were then left to dry for $24 \mathrm{~h}$. The water was allowed to drain naturally. The commercial hexaconazole (Anvil) solutions were at two concentrations; recommended dosage (4.5 g a.i) and double the recommended dosage $(9.0 \mathrm{~g}$ a.i $)$ were prepared in $30 \mathrm{~mL}$ and delivered evenly to the soil surface at the rate of $1 \mathrm{~mL} / \mathrm{min} /$ tube. The soil PVC tubes were left overnight. After $24 \mathrm{~h}$ of the application of hexaconazole, the soil PVC tubes were watered with $400 \mathrm{~mL}$ (equivalent to $377 \mathrm{~mm}$ of rainfall), $200 \mathrm{~mL}$ (equivalent to $223 \mathrm{~mm}$ of rainfall), and $100 \mathrm{~mL}$ (equivalent to $66 \mathrm{~mm}$ of rainfall). The amount of simulated rainfall used represents a similar amount to the natural rainfall received during the field study. The $500 \mathrm{~mL}$ beaker was placed at the bottom of each soil tube to collect the leachate. The experiment was conducted in triplicate for each concentration and rainfall volume used. Two days after the leaching was completed, the soil PVC tubes were divided into 5 segments: $0-10 \mathrm{~cm}, 10-20 \mathrm{~cm}, 20-30 \mathrm{~cm}, 30-40 \mathrm{~cm}$, and $40-50 \mathrm{~cm}$. Every soil segment was mixed homogenously before $25 \mathrm{~g}$ of soil was transferred into the conical flaks for residue analysis. The experiment was conducted in a randomized complete block design with three replications.

\section{Effects of Different Soil Structures}

To investigate the mobility of hexaconazole in two soil structures we used undisturbed and disturbed soil. The undisturbed soil was taken fresh from the site experiment plot by pushing soil PVC tubes into the soil from the soil surface up to $50 \mathrm{~cm}$ in depth and then carved out a soil core in it. The initial concentration used was $4.5 \mathrm{~g}$ a.i. and $9.0 \mathrm{~g}$ a.i. of hexaconazole, and simulated rainfall applied was $200 \mathrm{~mL}$ (equivalent to $223 \mathrm{~mm}$ of rainfall). The same procedures were used in this experiment as described earlier.

\section{Field Study Experiment}

The experiments were conducted under natural climatic conditions at field plot experiment at MPOBUKM Research Centre (101 $\left.47^{\prime} \mathrm{E}, 02^{\circ} 54^{\prime} \mathrm{N}\right)$. This site is the same site where the soil for laboratory study was taken. The field plot experiment consists of 225 7-year-old palm trees (DxP) and no history of prior hexaconazole application. The study was carried out in accordance with the studies that have been reported by Muhamad et al. [15]. The field experimental design was a complete randomized block with three replicates for each treatment and three control plots. The nine subplots were subjected to the following treatments, namely the recommended dosage, double the recommended dosage, and the control (without fungicide treatment). Healthy palms were treated with $90 \mathrm{~mL}$ of hexaconazole (Anvil) dissolved in $10 \mathrm{~L}$ water at a final concentration of $4.5 \mathrm{~g}$ a.i. for the recommended dosage, and for double the recommended dosage at $180 \mathrm{~mL}$ of hexaconazole dissolved in $10 \mathrm{~L}$ water at final concentration of $9.0 \mathrm{~g}$ a.i. The dosage was recommended by MPOB based on Idris et al. [16] with soil drenching method around the palm base as a preventive treatment for basal stem rot (BSR) or Ganoderma disease. Two rows of palms were used as buffer to separate the plots.

\section{Soil Method Extraction}

The extraction method from soil was similar to that previously published $[7,15]$. The soil (25 g) was transferred to the conical flask and $100 \mathrm{~mL}$ of dichloromethane was added. The mixer was subjected to an ultrasonic bath for $30 \mathrm{~min}$. The extract solution was filtered through sodium sulphate before $50 \mathrm{~mL}$ of the extract was transferred to the round-bottomed flask and then evaporated to dryness. After that, $1.0 \mathrm{~mL}$ of acetone was added to dissolve the residue and subjected to filter through a $0.45 \mu \mathrm{m}$ nylon-syringe filter before quantification by GC-ECD.

\section{Hexaconazole Residue Assay}

The determination of hexaconazole residue in the soil extract and leachate was accomplished by gas chromatography equipped with an electron capture detector (GC- $\mu \mathrm{ECD})$, and confirmation by gas chromatography mass spectrum (GC-MS) followed the method described by Muhamad et al. [15]. The limits of detection (LOD) and quantification (LOQ) for GC-ECD were 0.2 and $1.0 \mathrm{ng} / \mathrm{g}$, respectively. The recoveries of hexaconazole standard form soil obtained ranged from $100 \%$ to $106 \%$ at 5 levels of concentration. The mass spectrum for hexaconazole was found at $\mathrm{m} / \mathrm{z} 83,214$, and 174 .

\section{Statistical Analysis}

The experiment design was a randomized complete block with three replications. Data were averaged and subjected to an analysis of variance at $\alpha=0.05$ to compare residue means. Analysis of variance was used to evaluate the significant differences between treatments: application rates of hexaconazole, $4.5 \mathrm{~g}$ a.i. versus $9.0 \mathrm{~g}$ a.i, and simulated rainfall of $100 \mathrm{~mL}$, $200 \mathrm{~mL}$, and $400 \mathrm{~mL}$.

\section{Results and Discussion}

\section{Effect of Simulated Rainfall}

The effect of simulated rainfall on the mobility of hexaconazole at the recommended dosage (4.5 g a.i.) was shown in Fig. 1. It was observed that hexaconazole residues were detected in all depths of soil and leachate samples for applied treatments. For recommended dosage, the highest concentration of hexaconazole 
was found in the soil surface $(0-10 \mathrm{~cm})$ and the concentration was reduced as soil depth increased. The analysis of variance indicates that the concentration of hexaconazole detected in the soil was significantly different $(p<0.05)$ for each layer of soil. The total amount of hexaconazole found in the leachate was positively correlated with the volume treatments and significantly different at $(p<0.05)$. The concentration of hexacoanzole detected in leachate was increased in this order: $0.81 \mathrm{mg} \mathrm{L}^{-1}>0.47 \mathrm{mg} \mathrm{L}^{-1}>0.13 \mathrm{mg} \mathrm{L}^{-1}$ when applied at $400 \mathrm{~mL}, 200 \mathrm{~mL}$, and $100 \mathrm{~mL}$ of simulated rainfall, respectively.

The effect of simulated rainfall at double recommended dosage (9.0 $\mathrm{g}$ a.i.) on exaconazole mobility is presented in Fig. 2. The maximum and minimum amounts recovered for the hexaconazole were calculated to be $5.04 \mathrm{mg} \mathrm{kg}^{-1}$ and $0.40 \mathrm{mg} \mathrm{kg}^{-1}$ at a soil depth of $0-10 \mathrm{~cm}$ and $40-50 \mathrm{~cm}$, respectively, when watered with $100 \mathrm{~mL}$ simulated rainfall. The concentration of hexaconazole observed in the leachate samples was significantly different at $(p<0.05)$ when $100 \mathrm{~mL}, 200 \mathrm{~mL}$, and $400 \mathrm{~mL}$ of simulated rainfall were introduced.

The results of soil column study showed that the mobility of hexaconazole was directly proportional to the total amount of simulated rainfall accordingly


Fig. 1. Effect of simulated rainfall at recommended dosage (4.5 $\mathrm{g}$ a.i.) on the mobility of hexaconazole; error bars represent one standard error of the mean. in the order $400 \mathrm{~mL}>200 \mathrm{~mL}>100 \mathrm{~mL}$. The increased volume of the simulated rainfall was sufficient to cause downward movement of hexaconazole residues to the lower depths up to $50 \mathrm{~cm}$. These results were in agreement with Singh [11], who reported that increasing the amount of percolating water to 3 pore volumes (362 $\mathrm{mm}$ rainfall) increased the downward mobility of triazole fungicides (triadimefon, penconazole, hexaconazole, and propiconazole). Kördel and Klein [10] suggested that leaching of the pesticides in soils was governed largely by the amount of rainfall and soil type. Knowing that rainfall can be a major cause for rapid flow processes, such as the surface runoff and preferential flow, there is a significant control on the pesticide transport. Studies by Jhala et al. [17-18] and González-Delgado et al. [19] reported greater leaching of indaziflam with increasing application rate and amount of simulated rainfall in a soil column study under greenhouse conditions. A similar trend of mobility for other compounds was reported, such as metsulfuronmethyl [20], cyfluthrin [21], and glyphosate [22-23].

From adsorption studies, the leaching distribution of hexaconazole in soil column study suggested that hexaconazole was a mobile compound in sandy loam soil $\left(\mathrm{K}_{\mathrm{OC}}, 27.27\right)$ [24]. Nearly $53 \%$ and $63 \%$ of
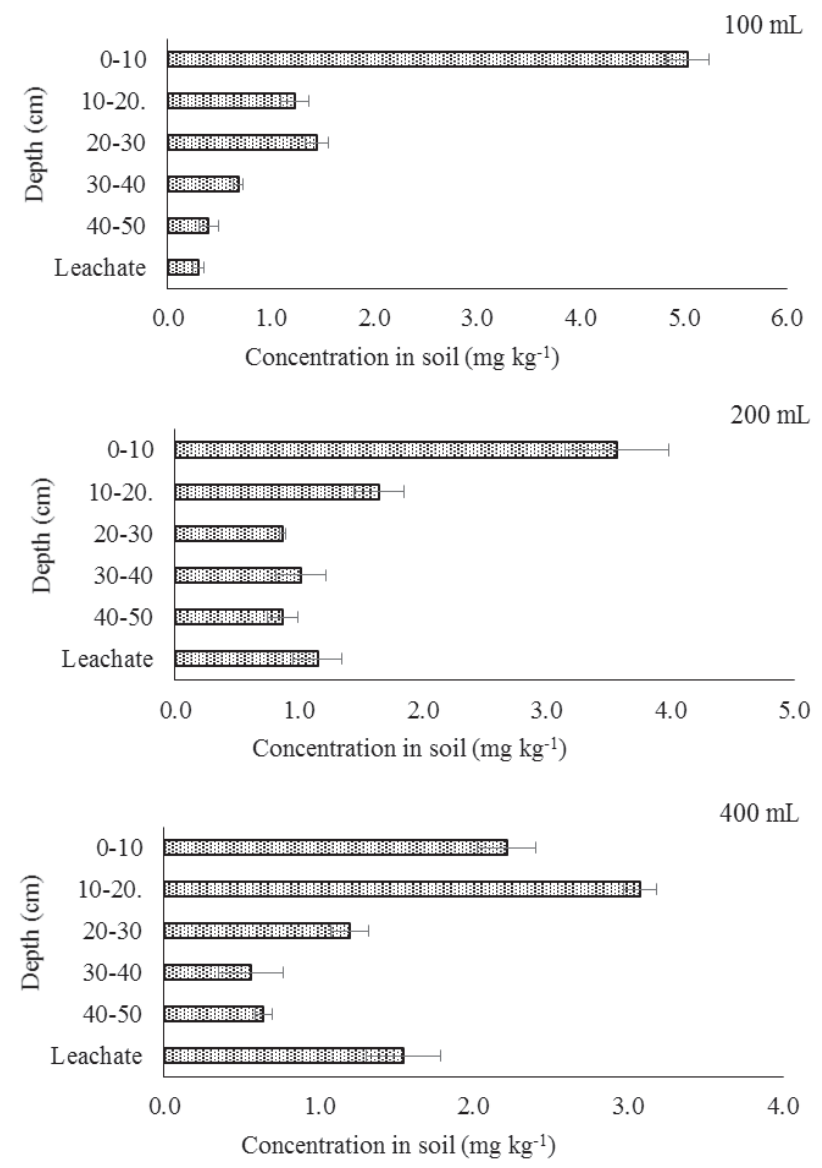

Fig. 2. Effect of simulated rainfall at doubled recommended dosage (9.0 g a.i.) on the mobility of hexaconazole; error bars represent one standard error of the mean. 
the hexaconazole were retained at soil surface when subjected to $100 \mathrm{~mL}$ simulated rainfall, and reduced to $23 \%$ and $18 \%$ when $400 \mathrm{~mL}$ of simulated rainfall was added at double and recommended dosage. A previous study by Singh [11] reported that $62 \%$ and $73 \%$ of hexaconazole were retained at the top $0-5 \mathrm{~cm}$ layer after percolating 1 to 3 pore volume of water. Fenoll et al. [12] found that nearly $88 \%$ of hexaconazole and $38 \%$ of triadimenol were recovered at the soil surface in the soil column study.

\section{Effects of Different Soil Structures}

The results for the effect of soil structure on the mobility of hexaconazole are illustrated in Fig. 3. Notably, the distribution of hexaconazole concentration in two soil structures (undisturbed and disturbed) showed a similar trend and it was observed that the concentration of hexaconazole decreased with increasing depth of soil for both treatments. However, there is no significant difference at $(p<0.05)$ observed in the concentration of hexaconazole detected in leachate for the undisturbed (1.074 $\left.\mathrm{mg} \mathrm{kg}^{-1}\right)$ and disturbed (0.874 $\left.\mathrm{mg} \mathrm{kg}^{-1}\right)$ soil columns.

As expected, a similar trend of leaching profile of hexaconazole for double recommended dosages was monitored. A high concentration of $3.877 \mathrm{mg} \mathrm{kg}^{-1}$ hexaconazole residue was detected at $0-10 \mathrm{~cm}$ depth in the undisturbed soil column and $3.038 \mathrm{mg} \mathrm{kg}^{-1}$ in the disturbed soil column. The concentrations of hexaconazole detected in leachate for the undisturbed and disturbed soil columns was significantly different at $(p<0.05)$ for double recommended dosage. The analysis of soil core showed a significant difference at $(p<0.5)$


Fig. 3. Effect of different soil structures on the mobility of hexaconazole; error bars represent one standard error of the mean. on mean concentration of hexaconazole at $0-10 \mathrm{~cm}$ and $10-20 \mathrm{~cm}$ depths for both treatments.

\section{Field Study Experiment}

The leaching profile of the hexaconazole applied at recommended dosage (4.5 g a.i./palm tree) and double recommended dosages ( $9.0 \mathrm{~g}$ a.i./palm tree) at different depths and days after application are shown in Fig. 4. The distribution pattern demonstrated that hexaconazole
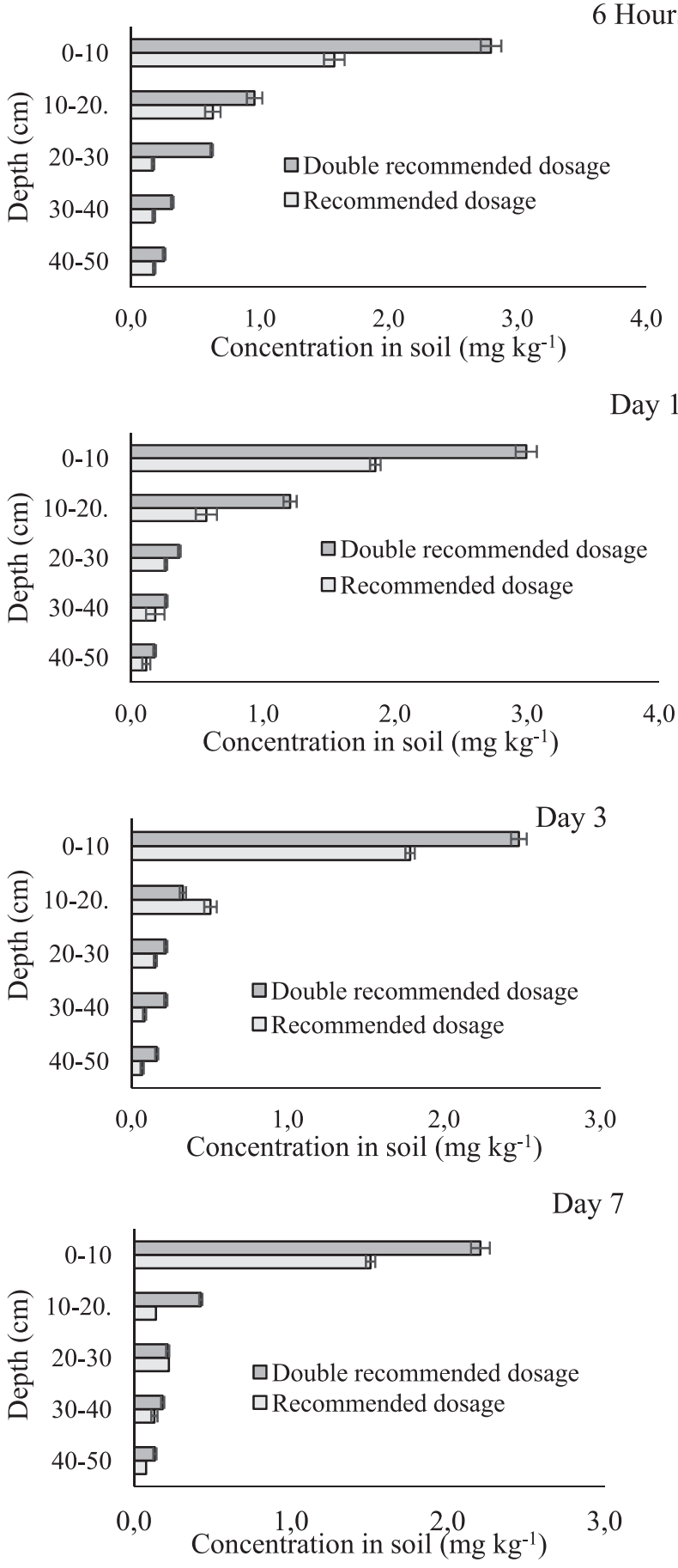

Fig. 4. Leaching profile of hexaconazole under field experiment; error bars represent one standard error of the mean. 
has a mobile leaching potential with more than $64 \%$ of fungicide remaining on the soil surface $(0-10 \mathrm{~cm})$ after 7 days of application. After application in the field, the presence of the hexaconazole is limited to the surface layer of the soil, favoring the association between soil particles. No residue of hexaconazole was found in the nearby streams and drains during the study period.

After 3 days of application, most of the hexaconazole residue appeared to be restricted to the top layer $(0-10 \mathrm{~cm})$, whereas $2.479 \mathrm{mg} \mathrm{kg}^{-1}$ and $1.783 \mathrm{mg} \mathrm{kg}^{-1}$ were found for the double recommended and recommended dosage plots, respectively. The data obtained followed the first-order kinetic equation with $\mathrm{R}^{2}$ value in the range of 0.707-0.926. Seven days after applications, the concentrations deposited found in the soil were $2.208 \mathrm{mg} \mathrm{kg}^{-1}$ and $1.508 \mathrm{mg} \mathrm{kg}^{-1}$, with $11 \%$ and $15 \%$ decline, detected in the double recommended and recommended dosage plots, respectively. The firstorder kinetic equation gave an adequate fit to the data $\left(\mathrm{R}^{2}=0.8316-0.6863\right)$. Even with low concentrations detected, the obtained result reflected the high mobility of the hexaconazole in the sandy loam soil column studied.

Comparing the two experimental conditions (laboratory versus field), the amount of hexaconazole remaining on the soil surface $(0-10 \mathrm{~cm})$ for laboratory (undisturbed soil column) and field study was in the range $1.850-2.993 \mathrm{mg} \mathrm{kg}^{-1}$ and $1.524-2.377 \mathrm{mg} \mathrm{kg}^{-1}$, respectively. The range of concentration of hexaconazole detected was similar to other tested depths of soils $(10-50 \mathrm{~cm})$. Hence, a similar pattern of the distribution of hexaconazole was monitored in the field experiments and laboratory conditions. The ANOVA results revealed that significant differences were observed $(p<0.05)$ for residual hexaconazole content in the soil layer $(0-50 \mathrm{~cm})$ in the undisturbed and disturbed soil columns, and field experiment (one day after application) at both rate of applications. However, the differences in downward movement of the hexaconazole between the two experimental methods were generally small. These results indicated that the mobility distribution of hexaconazole in sandy loam soil under laboratory conditions was in accordance with the observation in field experiments.

It should be noted that no rainfall was received and temperature recorded was in the range of $21-36^{\circ} \mathrm{C}$ during the field study period. No irrigation regime was applied for young oil palm trees following the common practice in oil palm plantations. Oil palms require an average rainfall of $150 \mathrm{~mm} / \mathrm{month}$, with dry periods not exceeding 2-3 months [25]. For this site experiment, the annual amount of rainfall received was $184 \mathrm{~mm} / \mathrm{month}$. In a previous study, we observed that mobility of hexaconazole at the field experiment was greatly influenced by soil cracks, active and abandoned root holes, and worm burrows - as clearly indicated in the image analysis [7]. The worm burrows were created by soil microbes such as worms, grubs, millipedes, and shredders, which live in moist oil palm plantation soil. Normally, the environment in an oil palm plantation is humid and damp as it has a full canopy that prevents it from direct sunlight and becomes an ideal habitat for soil microbes. In addition, countless oil palm fruits were left on the ground or buried, penetrating into soil and then consumed by soil microbes directly or indirectly [26]. We also believe that these findings might have resulted from the soil drenching method used during the experiment, which is known to use a large amount of water, which in turn can act as a medium for hexaconazole residue dissipated through the soil profile. Chai et al. [27] agreed that high dissipation rates for acephate and methamidophos in the soil profile were observed due to high moisture content of the soils from the soil drenching method applied, and attributed to the preferential flow in soil profile. Previous studies indicated that the main transport modes of pesticide particles under field conditions via surface runoff (of splash-eroded particles) and through preferential flow (macropores) [28-29]. Recently, Edwards et al. [30] suggested that rain events following application were observed as the primary transportation route through agricultural runoff for azoxystrobin and propiconazole movements in agricultural fields.

\section{Leaching Risk}

Results of the column study and field experiment demonstrated that hexaconazole has a high potential for leaching down to contaminate groundwater resources. In order to calculate the leaching potential of pesticides, a combination of the chemical properties of pesticides with soil properties, particularly the percentage of organic carbon, can offer a better understanding of the leaching potential of those pesticides. Gustafson [31] developed such an empirical model based on the persistence of pesticides (half-life $\mathrm{DT}_{50}$ or $\mathrm{t}_{1 / 2}$ ) and a fraction of organic carbon $\left(\mathrm{K}_{\mathrm{OC}}\right)$ obtained from the adsorption study. The relationship between these two parameters is referred to as the groundwater ubiquity score (GUS) index:

$$
\text { GUS Index }=\log \left(\mathrm{t}_{1 / 2}\right) \times\left[4-\log \left(\mathrm{K}_{\mathrm{OC}}\right)\right]
$$

In general, GUS $>2.8$ = high leachability (leacher); $1.8<$ GUS $<2.8=$ marginal leaching potential, and GUS $<1.8=$ low leachability (non-leacher) [31]. In accordance with the GUS index, higher values indicate that the pesticide will have higher mobility and cause a higher threat to groundwater resources.

In order to calculate the GUS index for hexaconazole, the $t_{1 / 2}$ value used was adopted from those published by Maznah et al. [7] and the $\mathrm{K}_{\mathrm{OC}}$ value was obtained from the adsorption study experiment [24], bearing in mind that the field study and adsorption study we carried out used the same soil as in the present study. The GUS index calculated for hexaconazole in the current study was 4.61 , indicating that hexaconazole 
can be categorized as leacher. The obtained GUS index value was in line with the results for the distribution of hexaconazole in the soil column study and field experiment. The calculated GUS index for hexaconazole obtained in the present study is in accordance with other studies by Pfeiffer [32], who reported that the triazole group of propiconazole, triticonazole, and penconazole GUS index were 2.04, 3.08, and 3.50, respectively.

Although the GUS index for hexaconazole of this study was higher than reported by IUPAC (2.05), this difference suggests that hexaconazole dissipation is probably influenced by soil type and experimental and environmental conditions. A similar observation was reported by Fenoll et al. [12, 33] in their studies on leaching potential of fungicides through soil columns. The authors reported that azoxyxtrobin, kresoximmethyl, hexaconazole, tebuconazole, and pyrimethanil have transient properties $(1.8<\mathrm{GUS}<2.8)$ in the clay-loam soil. In contrast, Kyung et al. [34] found that the GUS Index for hexaconazole in Korean soil was in the range $1.25-1.35$ when tested in soil, with $\mathrm{K}_{\mathrm{OC}}$ value ranging $1,552-1,400$.

\section{Conclusions}

In this paper, the experimental design was set up under laboratory and field conditions for evaluating the leaching behaviour of hexaconazole in the agricultural soil. As expected, hexaconazole was moderately mobile in the soil studied and the downward movement of hexaconazole was affected by the volume of simulated rainfall applied. Hexaconazole residues were recovered in all soil segments and leachate in soil column studies, and a higher concentration of hexaconazole was retained at the soil surface $(0-10 \mathrm{~cm})$. Overall, the comparisons between the undisturbed and disturbed soil column study and laboratory and field results showed the same pattern of leaching distribution. The GUS index for hexaconazole calculated in the present study was 4.61, categorized as a leacher. Therefore, the application of hexaconazole should be done with caution and follow good management practice due to its high risk to leach down through soil.

\section{Acknowledgements}

The authors would like to acknowledge the director general of the Malaysian Palm Oil Board (MPOB) for giving approval to publish these findings. And many thanks to all Rumah Tumbuhan UKM and MPOB-UKM Research Station staff for their kindness and hospitality. Special appreciation goes to those who were involved for their technical and editorial comments on the manuscript.

\section{References}

1. LAM C., CHIU S. Hexaconazole (Anvil 5SC), a costeffective fungicide for controlling white root disease in immature rubber. The Planter, 69, 465, 1993.

2. LAM C., LIM T. Efficacy of hexaconazole for the control of white rust on chrysanthemum and powdery mildew on roses. International Journal of Pest Management, 39, 156, 1993.

3. IDRIS A.S., ISMAIL S., ARIFFIN D., AHMAD H. Control of Ganoderma-infected palm-development of pressure injection and field applications. MPOB TT No. 131, 2002.

4. BROMILOW R.H., EVANS A.A., NICHOLLS P.H. Factors affecting degradation rates of five triazole fungicides in two soil types: 2. Field studies. Pest. Sci., 55, 1135, 1999.

5. BROMILOW R.H., EVANS A.A., NICHOLLS P.H. Factors affecting degradation rates of five triazole fungicides in two soil types: 1. Laboratory incubations. Pest. Sci., 55, 1129, 1999.

6. ZHANG Z., JIANG W., JIAN Q., SONG W., ZHENG Z., WANG D., LIU X. Residues and dissipation kinetics of triazole fungicides difenoconazole and propiconazole in wheat and soil in Chinese fields. Food Chemistry, 168, 396, 2015.

7. MAZNAH Z., HALIMAH M., ISMAIL S., IDRIS A.S. Dissipation of the fungicide hexaconazole in oil palm plantation. Environ. Sci. Pollut. Res., 22, 19648, 2015.

8. POTTER T.L., STRICKLAND T.C., JOO H., CULBREATH A.K. Accelerated soil dissipation of tebuconazole following multiple applications to peanut. J. Environ. Qual., 34, 1205, 2005.

9. WANG K., WU J., ZHANG H. Dissipation of difenoconazole in rice, paddy soil, and paddy water under field conditions. Ecotox. Environ. Safe., 86, 111, 2012.

10. KÖRDEL W., KLEIN M. Prediction of leaching and groundwater contamination by pesticides. Pure Appl. Chem., 78, 1081, 2006.

11. SINGH N. Mobility of four triazole fungicides in two Indian soils. Pest. Manag. Sci., 61, 191, 2005.

12. FENOLL J., RUIZ E., FLORES P., HELLIN P., NAVARRO $\mathrm{S}$. Leaching potential of several insecticides and fungicides through disturbed clay-loam soil columns. Int. J. Environ. An. Ch., 90, 276, 2010.

13. SHARMA K., SHARMA R., JOSEPH P., SAHA S., WALIA S. Sorption and leaching behavior of hexaconazole as influenced by soil properties. Toxicol. Environ. Chem., 95, 1090, 2013.

14. OECD. TG 312: Leaching in soil columns. Available online: http://archive.epa.gov/scipoly/sap/meetings/web/pdf/312 soil_column_leaching.pdf. (accessed on 19/3/2017)

15. MUHAMAD H., MAZNAH Z., ISMAIL B.S., IDRIS A.S. Determination of hexaconazole in field samples of an oil palm plantation. Drug Test. Anal., 4, 112, 2012.

16. IDRIS A.S., ISMAIL S., ARIFFIN D., AHMAD H. Prolonging the productive life of ganoderma-infected palms with hexaconazole. MPOB TT No. 214, 2004.

17. JHALA A.J., RAMIREZ A.H., SINGH, M. Leaching of indaziflam applied at two rates under different rainfall situations in Florida Candler soil. Bull. Environ. Contam. Toxicol. 88 (3), 326, 2012. 
18. JHALA A.J., SINGH M. Leaching of indaziflam compared with residual herbicides commonly used in Florida citrus. Weed Technol. 26 (3), 602, 2012.

19. GONZÁLEZ-DELGADO A.M., SHUKLA M.K., ASHIGH J., PERKINS, R. Effect of application rate and irrigation on the movement and dissipation of indaziflam. J. Environ. Sci. 51, 111, 2017.

20. ISMAIL B.S., OOI, K.E. Adsorption, desorption and mobility of metsulfuron-methyl in soils of the oil palm agroecosystem in Malaysia. Journal of Environmental Biology, 33 (3), 573, 2012.

21. ISMAIL B.S., CHOO L.Y., SALMIJAH S., HALIMAH M., TAYEB M.A. Adsorption, desorption and mobility of cyfluthrin in three Malaysian tropical soils of different textures. Journal of Environmental Biology, 36 (5), 1105, 2015.

22. ASLAM S., IQBAL A., DESCHAMPS M., RECOUS S., GARNIER, P. BENOIT P. Effect of rainfall regimes and mulch decomposition on the dissipation and leaching of S-metolachlor and glyphosate: a soil column experiment. Pest Manag. Sci. 71 (2), 278, 2015.

23. RASMUSSEN S.B., ABRAHAMSEN P., NIELSEN M.H., HOLM P.E., HANSEN S. Effects of single rainfall events on leaching of glyphosate and bentazone on two different soil types, using the DAISY model. Vadose Zone Journal, 14 (11), 2015.

24. MAZNAH Z., HALIMAH M., ISMAIL B.S., IDRIS A.S. Adsorption-desorption of hexaconazole in soils with respect to soil properties, temperature, and $\mathrm{pH}$. Turkish Journal of Agriculture - Food Science and Technology, 4 (6), 493, 2016.

25. VERHEYE, W. Growth and Production of Oil Palm. In: VERHEYE, W. (ed.), Land Use, Land Cover and Soil Sciences. Encyclopedia of Life Support Systems (EOLSS), UNESCO-EOLSS Publishers, Oxford, UK. http://www. eolss.net. 2010.

26. LIU M., YUSOFF M.M., MAKKY E.A., SALIHON J. Bacterial isolation from palm oil plantation soil for biodiesel production: isolation and molecular identification as inferred by 16s RNA. J Biotechnol Biomater, 4, 165, 2014.

27. CHAI L.K., MOHD-TAHIR N., HANSEN, S., HANSEN H.C.B. Dissipation and leaching of acephate, chlorpyrifos, and their main metabolites in field soils of Malaysia J. Environ. Qual. 38 (3), 1160, 2009.

28. KJAER J., VIBEKE E., JACOBESEN O.H., HANSEN N., DE JONGE L.W., OLSEN P. Transport modes and pathways of the strongly sorbing pesticides glyphosate and pendimethalin through structured drained soils. Chemosphere 84, 471, 2011.

29. GJETTERMANN B., PETERSEN C.T., KOCH C.B., SPLIID N.H., GRØN C., BAUN D.L., STYCZEN M. Particle-facilitated pesticide leaching from differently structured soil monoliths. J. Environ. Qual. 38 (6), 2382, 2009.

30. EDWFARDS P.G., MURPHY T.M., LYDY, M.J. Fate and transport of agriculturally applied fungicidal compounds, azoxystrobin and propiconazole. Chemosphere, 146, 450, 2016.

31. GUSTAFSON D.I. Groundwater ubiquity score: a simple method for assessing pesticide leachability. Environ. Toxicol. Chem., 8, 339, 1989.

32. PFEIFFER M. Groundwater Ubiquity Score (GUS). Available online: http://ptrpest.com/pdf/groundwater ubiquity.pdf. (accessed on 15/3/2017).

33. FENOLL J., RUIZ E., FLORES P., VELA N., HELLÍN P., NAVARRO $S$. Use of farming and agro-industrial wastes as versatile barriers in reducing pesticide leaching through soil columns. J. Hazard. Mater., 187, 206, 2011.

34. KYUNG K.-S., LEE B.-M., IHM Y.-B., LEE Y.-D., HAN S.-S., CHOI J.-H., KIM J.-H., RYU G.-H., LEE J.$\mathrm{K}$. Adsorption and leaching characteristics of fungicide hexaconazole. The Korean Journal of Pesticide Science, 8 , 46, 2004. 